\begin{tabular}{|l|l|l||}
\hline \multicolumn{2}{|c|}{ PublisherInfo } \\
\hline \hline PublisherName & $:$ & BioMed Central \\
\hline \hline PublisherLocation & $:$ & London \\
\hline \hline PublisherImprintName & $:$ & BioMed Central \\
\hline \hline
\end{tabular}

\title{
Chloroplast transfer
}

\begin{tabular}{|l|l|l||}
\hline \multicolumn{2}{|c|}{ ArticleInfo } \\
\hline \hline ArticleID & $:$ & 4693 \\
\hline \hline ArticleDOI & $:$ & $10.1186 /$ gb-spotlight-20030206-01 \\
\hline \hline ArticleCitationID & $:$ & spotlight-20030206-01 \\
\hline \hline ArticleSequenceNumber & $:$ & 45 \\
\hline \hline ArticleCategory & $:$ & Research news \\
\hline ArticleFirstPage & $:$ & 1 \\
\hline \hline ArticleLastPage & $:$ & 2 \\
\hline \hline & & RegistrationDate : 2003-2-6 \\
\hline ArticleHistory & $:$ & OnlineDate \\
\hline \hline ArticleCopyright & $:$ & BioMed Central Ltd2003-6-6 \\
\hline \hline ArticleGrants & $:$ & \\
\hline \hline ArticleContext & $:$ & 130594411 \\
\hline \hline
\end{tabular}




\section{Jonathan B Weitzman}

Email: jonathanweitzman@hotmail.com

There is substantial evolutionary evidence for gene transfer from the chloroplast to the nucleus. In an Advanced Online Publication in Nature Huang et al. report the results of experiments designed to measure the rate of transfer of chloroplast DNA (cpDNA) into the nucleus in Nicotiana tabacum tobacco plants (Nature, 5 February 2003, doi:10.1038/nature01435). They engineered the chloroplast genome by inserting a neomycin phosphotransferase reporter gene (neoSTLS2) that confers kanamycin resistance only when it is transposed to the nucleus. A screen of 250,000 seedlings led to the isolation of 16 kanamycin-resistant plants that showed stable inheritance of neoSTLS2. Huang et al. estimate the rate of cpDNA transfer as one transposition event in about 16,000 pollen grains.

\section{References}

1. Evolutionary analysis of Arabidopsis, cyanobacterial, and chloroplast genomes reveals plastid phylogeny and thousands of cyanobacterial genes in the nucleus.

2. Nature, [http://www.nature.com/nature/]

This PDF file was created after publication. 